\title{
ANALISIS POTENSI DAN UNJUK KERJA PERENCANAAN PEMBANGKIT LISTRIK TENAGA SURYA (PLTS) DI DEPARTEMEN TEKNIK ELEKTRO UNIVERSITAS DIPONEGORO MENGGUNAKAN SOFTWARE PVSYST 6.43
}

\author{
Muhammad Alvin Ridho*), Bambang Winardi dan Agung Nugroho \\ Departemen Teknik Elektro, Universitas Diponegoro \\ Jl. Prof. Sudharto, SH, Kampus UNDIP Tembalang, Semarang 50275, Indonesia \\ ${ }^{*}$ E-mail: malvinridho18@gmail.com
}

\begin{abstract}
Abstrak
Indonesia merupakan negara yang secara geografis terletak tepat berada di garis khatulistiwa dan memberikan beragam keuntungan serta potensi besar dalam hal pemanfaatan energi matahari. Hal ini dikarenakan besarnya radiasi matahari bergantung pada letak garis lintang, kondisi atmosfer, dan posisi matahari terhadap garis khatulistiwa. Indonesia mempunyai tingkat radiasi rata-rata yang relatif tinggi yaitu sebesar $4,80 \mathrm{kWh} / \mathrm{m}^{2} /$ hari. Hal ini adalah merupakan sebuah keuntungan besar bagi Indonesia dalam hal pemanfaatan dan pembangkitan energi matahari menjadi energi listrik (PLTS). Departemen Teknik Elektro Universitas Diponegoro, sebagai salah satu jurusan dan program studi terbaik di Indonesia memiliki sebuah sarana parkir sepeda motor yang belum teroptimalkan dengan baik. Dengan tingkat radiasi matahari yang cukup tinggi tiap harinya, departemen yang terletak di Tembalang, Semarang, Jawa Tengah ini dapat memanfaatkan sarana parkir sepeda motornya menjadi sebuah siteplan PLTS yang cukup besar. Melalui software PVSyst 6.43, potensi dan kinerja dari perencanaan PLTS di Departemen Teknik Elektro Universitas Diponegoro ini diperkirakan memiliki potensi 272,8 MWh tiap tahunnya. Dengan sistem PLTS yang terhubung jaringan (OnGrid), PLTS ini memiliki rasio penghematan energi listrik guna penggunaan sendiri dan penjualan kembali menuju jala-jala PLN (Grid) yang cukup besar pula, yaitu 197,67 MWh dan 75,11 MWh tiap tahunnya.
\end{abstract}

Kata Kunci: PLTS, OnGrid, PVSyst

\begin{abstract}
Indonesia is countries that are geographical located right in the equator and variously advantage and the wide for the the use of solar energy. It was because the size of the solar radiation dependent on the latitude, atmospheric conditions, and the position of the sun to the equator. Indonesia has average of the solar radiation level relatively high is as much as 4,80 $\mathrm{kWh} / \mathrm{m} 2$ per day. This is an advantage for indonesia in the utilization of solar energy and whenever into electrical energy (PLTS). The department of Electrical Engineering Diponegoro University, as one of majors and course of best college in Indonesia has a parking facility motorcycle who doesn't optimized well. With a solar radiation daily is quite high, the department that located in Tembalang, Semarang, Central Java this can use parking facility the motorcycle into a PLTS siteplan enough. Through software PVSyst 6.43, potential and the performance of planning PLTS in the department of Electrical Engineering Diponegoro University, is expected to have the potential 272,8 MWh every year. With the PLTS system connected tissue (OnGrid), this PLTS having the ratio of electric energy saving to own use and sale back to network PLN (Grid) which has a quite large also, namely 197,67 MWh and 75,11 MWh every year.
\end{abstract}

Keywords: PLTS, OnGrid, PVSyst

\section{Pendahuluan}

Indonesia merupakan negara yang secara geografis terletak tepat berada di garis khatulistiwa dan memberikan beragam keuntungan serta potensi besar dalam hal pemanfaatan energi matahari [1]. Hal ini dikarenakan besarnya radiasi matahari bergantung pada letak garis lintang, kondisi atmosfer, dan posisi matahari terhadap garis khatulistiwa [2]. Indonesia mempunyai tingkat radiasi rata-rata yang relatif tinggi yaitu sebesar 4,8 $\mathrm{kWh} / \mathrm{m}^{2} /$ hari [3]. Hal ini adalah merupakan sebuah keuntungan besar bagi Indonesia dalam hal pemanfaatan dan pembangkitan energi matahari menjadi energi listrik (PLTS). Universitas Diponegoro sebagai salah satu Perguruan Tinggi Negeri (PTN) terbesar di Indonesia memiliki 7 buah kampus yang tersebar diberagam daerah DI Jawa Tengah sebagai sarana perkuliahan. Salah satunya terletak di Jalan Prof. Soedarto, S.H., Kelurahan Tembalang, Kecamatan Tembalang, Kota Semarang, Jawa 
Tengah. Kampus UNDIP Tembalang ini merupakan pusat dari segala aktivitas civitas akademika Universitas Diponegoro yang terdiri dari 11 fakultas dan 1 sekolah vokasi diatas lahan seluas $1.352 .054 \mathrm{~m}^{2}$. Departemen Teknik Elektro sebagai salah satu pioneer dan departemen terbesar di Fakultas Teknik Universitas Diponegoro memiliki beragam fasilitas diantaranya adalah gedung kuliah dan administrasi, laboratorium, perpustakaan, sarana olahraga, sarana parkir kendaraan bermotor, kantin, musholla, dll. Sarana parkir kendaraan bermotor di Departemen Teknik Elektro terbagi menjadi dua bagian, sarana parkir mobil dan sepeda motor. Sarana parkir sepeda motor Departemen Teknik Elektro Universitas Diponegoro berbentuk lahan parkir terbuka dengan total lahan seluas $980,0505 \mathrm{~m}^{2} \quad$ [4]. Namun, terdapat permasalahan bahwa lahan sarana parkir ini berbentuk ruang terbuka yang luas dan dapat dioptimalkan nilai guna pemanfaatan lahannya dengan menjadikan PLTS sebagai atap sarana parkir sepeda motor tsb. Selain dapat meningkatkan nilai guna lahan, hal ini pun menjadi solusi pengurangan pemakaian energi listrik harian yang dicatu oleh PLN sehingga dapat menghemat biaya yang cukup besar [5]. Penulisan penelitian ini bertujuan guna merancang dan menganalisis unjuk kerja Pembangkit Listrik Tenaga Surya (PLTS) dengan memanfaatkan serta meoptimalkan penggunaan lahan sarana parkir sepeda motor di Departemen Teknik Elektro Universitas Diponegoro sebagai pencatu daya beban listrik yang terhubung dengan jala-jala PLN (OnGrid) sebagai sumber energi listrik di Departemen Teknik Elektro Universitas Diponegoro menggunakan software PVSyst versi 6.43.

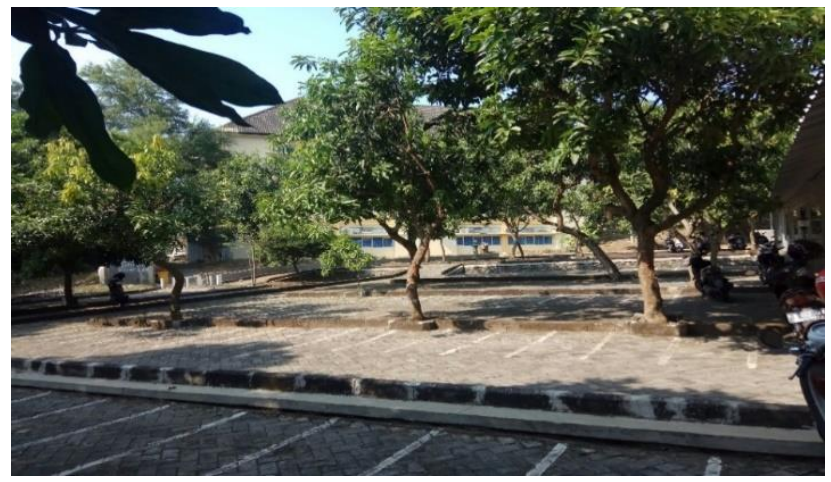

Gambar 1. Sarana Parkir Sepeda Motor Departemen Teknik Elektro Universitas Diponegoro

\section{Metode}

\subsection{Perancangan Simulasi}

Dalam pengerjaan Penelitian ini, digunakan dua buah skenario simulasi guna mengetahui pengaruh bayangan/ shading factor terhadap unjuk kerja PLTS dalam memproduksi energi listrik tiap bulan dan tahun secara periodik. Adapun diagram alir/ flowchart Penelitian ini adalah sebagai berikut:

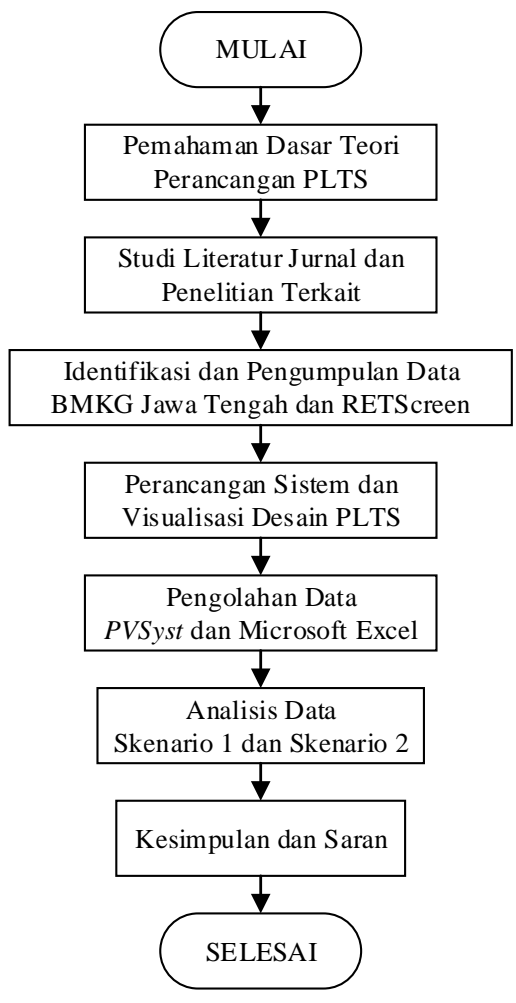

Gambar 2. Diagram Alir Pengerjaan Penelitian

\subsection{Pengambilan Data}

Pada tahap pengerjaan Penelitian ini, dilakukan pengambilan data di Badan Meteorologi Klimatologi dan Geofisika (BMKG) Jawa Tengah guna mengetahui beragam parameter meteorologi dan klimatologi di wilayah perencanaan yakni di wilayah Kota Semarang selama periode tahun 2015 hingga 2017 [6]. Adapun beberapa data yang diperlukan guna pengerjaan penelitian ini adalah sebagai berikut:

Tabel 1. Lama Penyinaran Matahari (\%)

\begin{tabular}{lccc}
\hline BULAN & \multicolumn{3}{c}{ TAHUN } \\
& 2015 & 2016 & 2017 \\
\hline Januari & 50 & 69 & 69 \\
Februari & 58 & 43 & 53 \\
Maret & 66 & 65,6 & 62 \\
April & 68 & 67,8 & 69 \\
Mei & 89 & 78,1 & 75 \\
Juni & 87 & 71,7 & 77 \\
Juli & 95 & 95 & 74 \\
Agustus & 97 & 88,3 & 89 \\
September & 99 & 80,7 & 93 \\
Oktober & 98 & 57,2 & 85 \\
November & 99 & 52,2 & 44 \\
Desember & 50 & 37,6 & 46 \\
Rata-Rata & 79,73 & 67,18 & 69,67 \\
\hline
\end{tabular}


Tabel 2. Intensitas Radiasi Matahari $\left(\mathrm{kWh} / \mathrm{m}^{2} / \mathrm{hari}\right)$

\begin{tabular}{cccc}
\hline BULAN & \multicolumn{3}{c}{ TAHUN } \\
& 2015 & 2016 & 2017 \\
\hline Januari & 7,769 & 8,624 & 8,62 \\
Februari & 8,834 & 6,318 & 8,216 \\
Maret & 8,826 & 9,173 & 8,577 \\
April & 7,328 & 8,833 & 7,052 \\
Mei & 9,909 & 7,765 & 7,507 \\
Juni & 9,527 & 7,117 & 8,216 \\
Juli & 9,608 & 7,836 & 9,43 \\
Agustus & 9,782 & 8,811 & 10,079 \\
September & 10,229 & 9,322 & 9,37 \\
Oktober & 10,205 & 7,732 & 9,86 \\
November & 10,014 & 8,080 & 7,13 \\
Desember & 7,664 & 7,421 & 7,392 \\
Rata-Rata & 9,141 & 8,086 & 8,454 \\
\hline
\end{tabular}

Tabel 3. Temperatur Rata-rata $\left({ }^{\circ} \mathrm{C}\right)$

\begin{tabular}{cccc}
\hline BULAN & \multicolumn{3}{c}{ TAHUN } \\
& 2015 & 2016 & 2017 \\
\hline Januari & 26,9 & 28,5 & 28,5 \\
Februari & 26,9 & 27,5 & 26,8 \\
Maret & 27,5 & 28,4 & 27,6 \\
April & 27,8 & 28,0 & 28,0 \\
Mei & 28,7 & 29,3 & 28,9 \\
Juni & 28,1 & 28,6 & 28,0 \\
Juli & 28,1 & 28,5 & 28,1 \\
Agustus & 28,0 & 28,5 & 28,1 \\
September & 29,0 & 28,3 & 28,9 \\
Oktober & 30,2 & 28,2 & 28,9 \\
November & 29,6 & 28,1 & 27,7 \\
Desember & 28,2 & 27,6 & 27,6 \\
Rata-Rata & 28,24 & 28,29 & 28,08 \\
\hline
\end{tabular}

Selain diperoleh dari BMKG Jawa Tengah, pengambilan data guna menunjang Penelitian ini diperoleh juga melalui pengukuran perkiraan penggunaan beban harian di Departemen Elektro Universitas Diponegoro. Data ini dibutuhkan sebagai estimasi penggunaan beban harian yang dicatu oleh listrik PLN baik dalam hari kerja maupun hari libur. Berdasarkan data pengukuran tersebut, diperoleh data bahwa beban harian saat hari kerja (weekdays) sebesar $1271 \mathrm{kWh} /$ hari sedangkan saat hari libur (weekend) penggunaan beban harian hanya sebesar $37,3 \mathrm{kWh} /$ hari.

\subsection{Simulasi}

Pada tahapan simulasi ini, digunakan perangkat lunak/ software PVSyst versi 6.43 sebagai perangkat utama guna menganalisis unjuk kerja dan potensi pembangkitan energi listrik dari perancangan PLTS Departemen Teknik Elektro Universitas Diponegoro ini. Dengan menggunakan dua skenario, yakni tanpa memperhatikan pengaruh bayangan dilingkungan sekitar dan dengan memperhatikannya/ shading factor maka tahapan simulasi ini memiliki diagram alir seperti berikut ini:

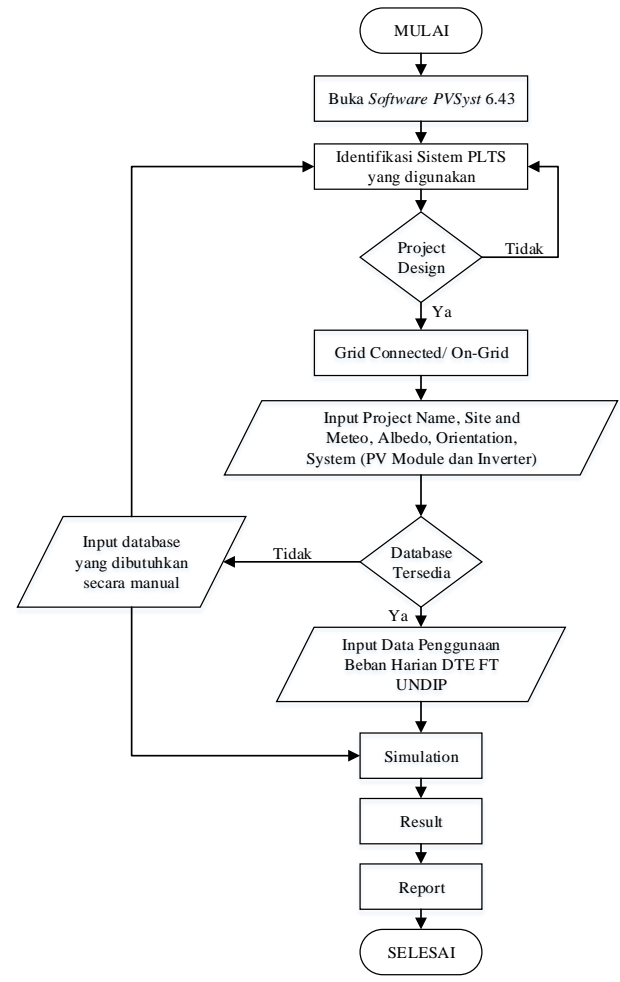

Gambar 3. Diagram Alir Simulasi Skenario 1

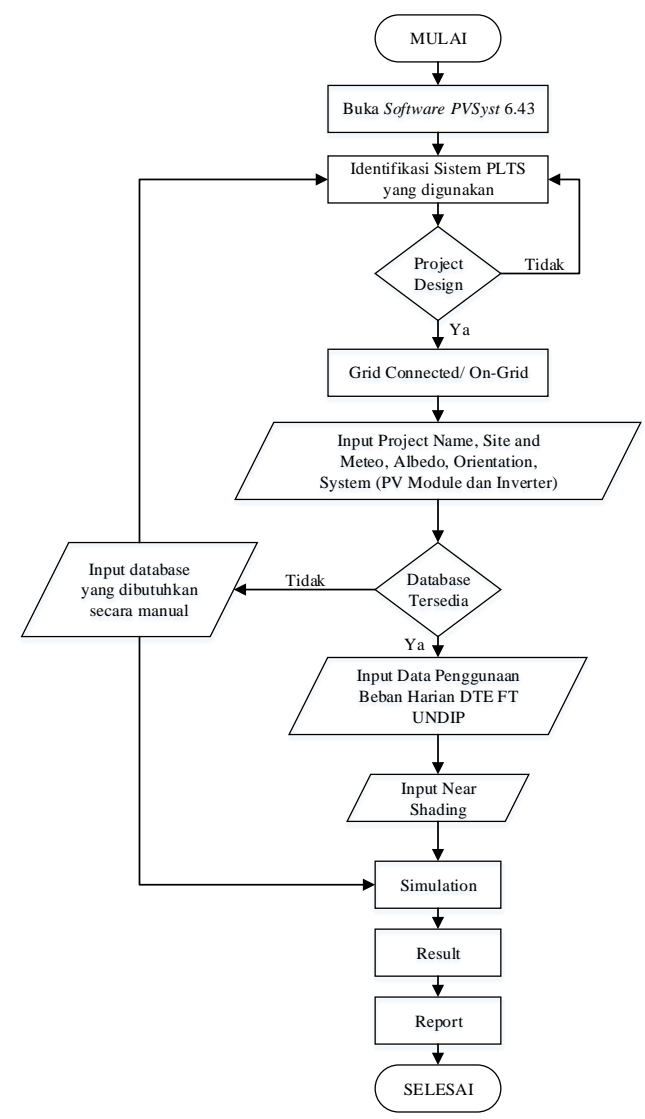

Gambar 4. Diagram Alir Simulasi Skenario 2 
PVSyst merupakan paket softwarel perangkat lunak yang digunakan untuk proses pembelajaran, pengukuran (sizing), dan analisa data dari sistem PLTS secara lengkap. PVSyst dikembangkan oleh Universitas Genewa, yang terbagi ke dalam sistem terinterkoneksi jaringan (gridconnected), sistem berdiri sendiri (stand-alone), sistem pompa (pumping), dan jaringan arus searah untuk transportasi publik (DC-grid) [7]. PVSyst juga dilengkapi database dari sumber data meteorologi yang luas dan beragam, serta data komponen-komponen PLTS. Beberapa contoh sumber data meteorologi yang dapat digunakan pada PVSyst yaitu bersumber dari MeteoNorm $V 6.1$ (interpolasi 1960-1990 atau 1981-2000), NASA-SSE (1983-2005), PVGIS (untuk Eropa dan Afrika), Satel-Light (untuk Eropa), TMY2/3 dan SolarAnywhere (untuk USA), EPW (untuk Kanada), RetScreen, Helioclim, dan SolarGIS (berbayar) [8].

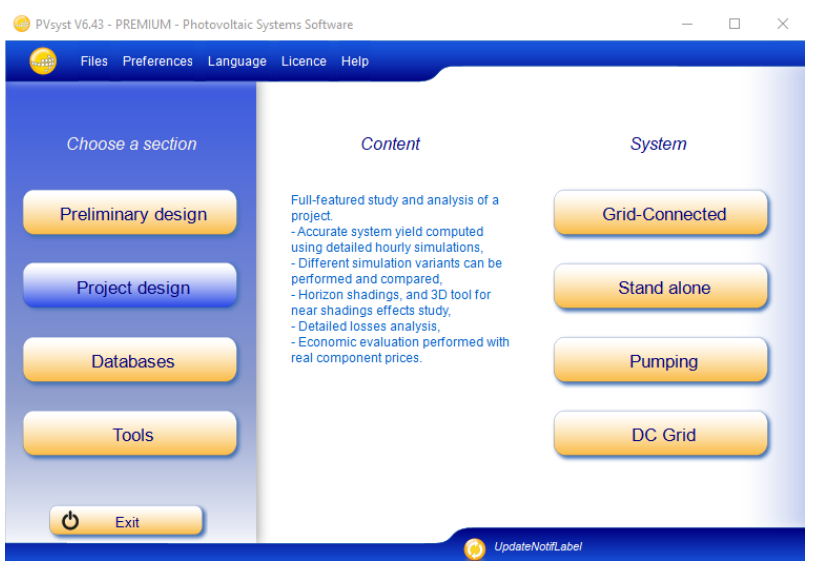

Gambar 5. Tampilan Menu Awal Software PVSyst 6.43

\section{Hasil dan Analisis \\ 3.1 Hasil Simulasi PVSyst 6.43 Skenario 1}

Berdasarkan perencanaan wilayah dan sistem beserta spesifikasi yang digunakannya, dengan menggunakan kondisi skenario 1 yakni dengan mengabaikan pengaruh bayangan/ shading factor perangkat lunak PVSyst 6.43 maka diperoleh hasil sebagai berikut:

Tabel 4. Hasil Simulasi Skenario 1 dengan PVSyst 6.43

\begin{tabular}{lrrrrrr}
\hline & $\begin{array}{r}\text { GlobHor } \\
\text { kWh/m2 }\end{array}$ & $\begin{array}{r}\text { Globlnc } \\
\text { kWh/m' }\end{array}$ & $\begin{array}{c}\text { EArray } \\
\text { MWh }\end{array}$ & $\begin{array}{c}\text { ELoad } \\
\text { MWh }\end{array}$ & $\begin{array}{c}\text { E User } \\
\text { MWh }\end{array}$ & $\begin{array}{c}\text { E_Grid } \\
\text { MWh }\end{array}$ \\
\hline January & 267.2 & 248.9 & 24.33 & 29.54 & 17.45 & 5.808 \\
February & 230.0 & 221.3 & 21.93 & 25.73 & 15.20 & 5.759 \\
March & 265.9 & 266.8 & 25.93 & 28.30 & 17.81 & 7.049 \\
April & 211.6 & 222.3 & 22.07 & 27.03 & 15.29 & 5.827 \\
May & 232.7 & 254.2 & 24.70 & 29.54 & 17.54 & 6.158 \\
June & 246.5 & 274.7 & 26.05 & 27.03 & 17.59 & 7.443 \\
July & 292.3 & 323.1 & 29.15 & 28.30 & 19.96 & 8.094 \\
August & 312.4 & 333.8 & 29.65 & 29.54 & 21.19 & 7.354 \\
September & 281.1 & 287.1 & 26.73 & 25.80 & 17.17 & 8.536 \\
October & 305.7 & 298.5 & 27.69 & 29.54 & 19.55 & 7.072 \\
November & 213.9 & 203.0 & 20.41 & 28.27 & 14.19 & 5.277 \\
December & 229.2 & 213.1 & 21.42 & 27.07 & 13.99 & 6.432 \\
Year & 3088.5 & 3146.9 & 300.06 & 335.70 & 206.94 & 80.809 \\
\hline
\end{tabular}

Berdasarkan tabel 4, diketahui bahwa energi listrik yang dihasilkan Pembangkit Listrik Tenaga Surya Departemen Teknik Elektro Universitas Diponegoro dengan skenario 1 adalah sebesar 300,06 MWh setiap tahunnya sebelum dikonversi menjadi listrik arus bolak-balik oleh inverter. Setelah melalui proses konversi pembalikan arus, energi listrik yang dihasilkan berkurang menjadi 287,8 MWh per tahun dengan pembagian 206,94 MWh digunakan guna mencatu daya beban Departemen Teknik Elektro Universitas Diponegoro dan 80,809 MWh sisanya dijual atau dikirimkan pada sistem jala-jala PLN (Grid).

Normalized productions (per installed kWp): Nominal power 125 kWp

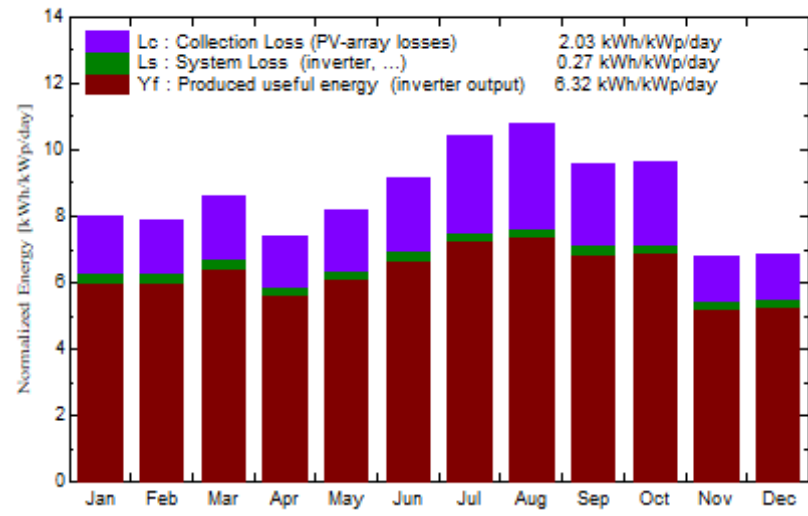

Gambar 6. Grafik Produksi Energi Listrik Kondisi Normal

Berdasarkan gambar 6, energi listrik yang dihasilkan PLTS Departemen Teknik Elektro Universitas Diponegoro dengan menerapkan skenario 1 memiliki hasil produksi energi listrik yang beragam dan fluktuatif ditiap bulannya. Dengan produksi energi listrik terbesar pada bulan Agustus dan terendah pada bulan November.

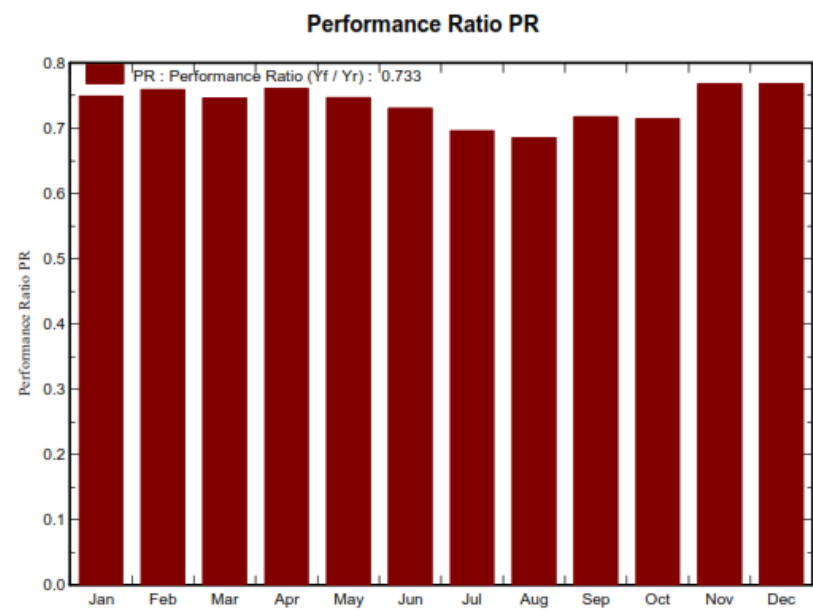

Gambar 7. Grafik Rasio Kinerja (Peformance Ratio)

Performance Ratio atau rasio kinerja dari sistem PLTS Departemen Teknik Elektro Universitas Diponegoro adalah rasio atau tingkat perbandingan energi listrik yang diproduksi secara efektif (digunakan) dengan energi listrik 
yang akan dihasilkan jika sistem terus bekerja dalam kondisi standar (STC). Pada simulasi PVSyst skenario 1 ini, sistem PLTS Departemen Teknik Elektro Universitas Diponegoro memiliki tingkat rasio kinerja sebesar 73,3\%.

\subsection{Hasil Simulasi PVSyst 6.43 Skenario 2}

Sedangkan dengan menggunakan skenario 2 yaitu dengan menganggap adanya pegaruh bayangan disekitar lokasi PLTS/ shading factor, maka hasil yang diperoleh adalah sebagai berikut:

Tabel 5. Hasil Simulasi Skenario 2 dengan PVSyst 6.43

\begin{tabular}{lrrcccc}
\hline & $\begin{array}{r}\text { GlobHor } \\
\text { kWh/m2 }\end{array}$ & $\begin{array}{r}\text { Globlnc } \\
\text { kWh/m2 }\end{array}$ & $\begin{array}{l}\text { EArray } \\
\text { MWh }\end{array}$ & $\begin{array}{l}\text { ELoad } \\
\text { MWh }\end{array}$ & $\begin{array}{l}\text { E User } \\
\text { MWh }\end{array}$ & $\begin{array}{l}\text { E_Grid } \\
\text { MWh }\end{array}$ \\
\hline January & 267.2 & 248.9 & 23.11 & 29.54 & 16.63 & 5.413 \\
February & 230.0 & 221.3 & 20.90 & 25.73 & 14.47 & 5.468 \\
March & 265.9 & 266.8 & 24.98 & 28.30 & 17.23 & 6.686 \\
April & 211.6 & 222.3 & 21.07 & 27.03 & 14.71 & 5.413 \\
May & 232.7 & 254.2 & 23.16 & 29.54 & 16.54 & 5.622 \\
June & 246.5 & 274.7 & 24.09 & 27.03 & 16.37 & 6.729 \\
July & 292.3 & 323.1 & 27.43 & 28.30 & 18.90 & 7.461 \\
August & 312.4 & 333.8 & 28.49 & 29.54 & 20.49 & 6.899 \\
September & 281.1 & 287.1 & 25.89 & 25.80 & 16.75 & 8.115 \\
October & 305.7 & 298.5 & 26.60 & 29.54 & 18.96 & 6.580 \\
November & 213.9 & 203.0 & 19.15 & 28.27 & 13.39 & 4.822 \\
December & 229.2 & 213.1 & 20.12 & 27.07 & 13.23 & 5.900 \\
Year & 3088.5 & 3146.9 & 284.97 & 335.70 & 197.67 & 75.110 \\
\hline
\end{tabular}

Berdasarkan tabel 5, energi listrik yang dihasilkan Pembangkit Listrik Tenaga Surya Departemen Teknik Elektro Universitas Diponegoro dengan skenario 2 adalah sebesar 284,97 MWh setiap tahunnya sebelum dikonversi menjadi listrik arus bolak-balik oleh inverter. Setelah melalui proses konversi pembalikan arus, energi listrik yang dihasilkan berkurang menjadi $272,8 \mathrm{MWh}$ per tahun dengan pembagian 197,67 MWh digunakan guna mencatu daya beban Departemen Teknik Elektro Universitas Diponegoro dan 75,110 MWh sisanya dijual atau dikirimkan pada sistem jala-jala PLN (Grid).

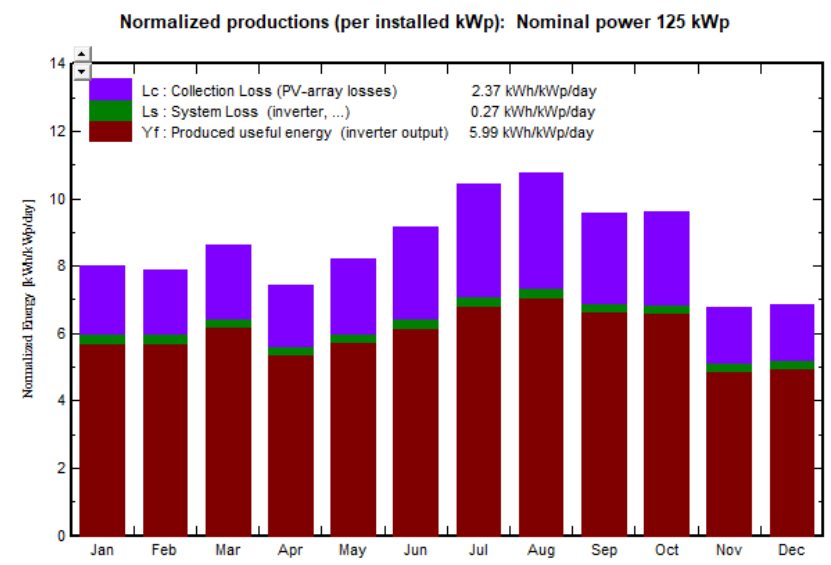

Gambar 8. Grafik Produksi Energi Listrik Kondisi Normal
Berdasarkan gambar 8, energi listrik yang dihasilkan Pembangkit Listrik Tenaga Surya Departemen Teknik Elektro Universitas Diponegoro dengan menerapkan skenario 2 yakni dengan menggunakan faktor bayangan/ shading factor yaitu memiliki hasil produksi energi listrik yang beragam dan fluktuatif ditiap bulannya. Dengan produksi energi listrik terbesar pada bulan Agustus dan terendah pada bulan November.

Performance Ratio PR

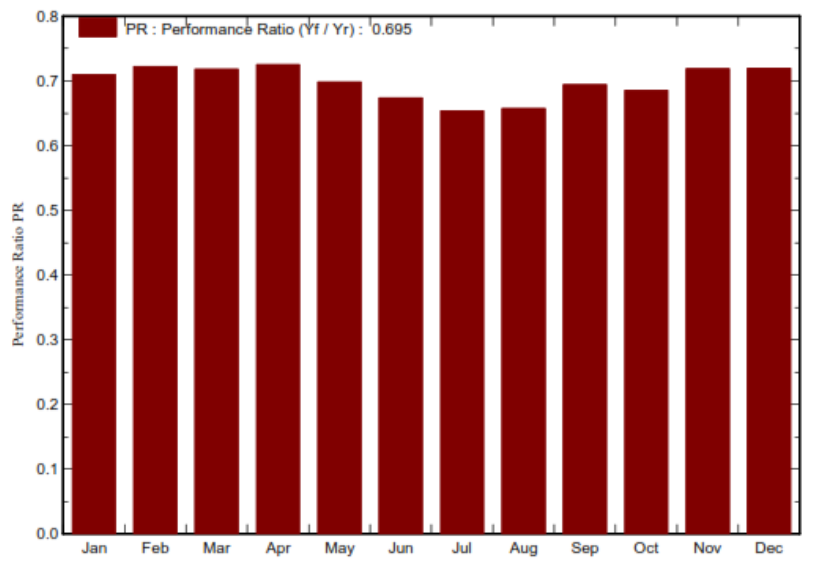

Gambar 9. Grafik Rasio Kinerja (Peformance Ratio)

Performance Ratio atau rasio kinerja dari sistem Pembangkit Listrik Tenaga Surya Departemen Teknik Elektro Universitas Diponegoro pada simulasi PVSyst skenario 2 ini, sistem Pembangkit Listrik Tenaga Surya Departemen Teknik Elektro Universitas Diponegoro memiliki tingkat rasio kinerja sebesar 69,5\%.

\subsection{Analisis Perbandingan Hasil Simulasi}

Berdasarkan hasil simulasi software PVSyst PLTS Departemen Teknik Elektro Universitas Diponegoro pada skenario 1 dan skenario 2 dapat dilihat bahwa, produksi energi listrik yang dihasilkan PLTS melalui simulasi skenario 2 lebih kecil nilainya yaitu 272,8 MWh per tahun, dibandingkan dengan simulasi skenario 1 yaitu 287,8 MWh per tahun. Selisih produksi energi listrik rata-rata untuk setiap bulannya yaitu sebesar 1,246 MWh dan total selisih produksi energi per tahun yaitu sebesar $15 \mathrm{MWh}$. Hal ini membuktikan bahwa adanya shading factor pada lokasi PLTS Departemen Teknik Elektro Universitas Diponegoro dapat mempengaruhi dan menyebabkan penurunan jumlah produksi energi listrik PLTS per tahun yaitu sebesar $5.2 \%$ yaitu sejumlah $15 \mathrm{MWh}$ dari total jumlah energi listrik tanpa adanya shading yaitu 287,8 MWh, hal ini dapat dilihat pada tabel 6 dan gambar 10 sebagai berikut: 
Tabel 6. Perbandingan Hasil Simulasi Produksi Energi Listrik

\begin{tabular}{cccl}
\hline BULAN & $\begin{array}{c}\text { E Avail 1 } \\
\text { (MWh) }\end{array}$ & $\begin{array}{c}\text { E Avail 2 } \\
\text { (MWh) }\end{array}$ & $\begin{array}{c}\text { Selisih } \\
\text { (MWh) }\end{array}$ \\
\hline Januari & 23,258 & 22,04 & 1,215 \\
Februari & 20,959 & 19,94 & 1,021 \\
Maret & 24,859 & 23,92 & 0,943 \\
April & 21,117 & 20,12 & 0,994 \\
Mei & 23,698 & 22,16 & 1,536 \\
Juni & 25,033 & 23,10 & 1,934 \\
Juli & 28,054 & 26,36 & 1,693 \\
Agustus & 28,544 & 27,39 & 1,115 \\
September & 25,706 & 24,87 & 0,841 \\
Oktober & 26,662 & 25,54 & 1,082 \\
November & 19,467 & 18,21 & 1,255 \\
Desember & 20,442 & 19,13 & 1,292 \\
Total & 287,739 & 272,78 & 14,961 \\
\hline
\end{tabular}

Perbandingan Hasil Simulasi Produksi Energi Listrik Skenario1 dan Skenario 2

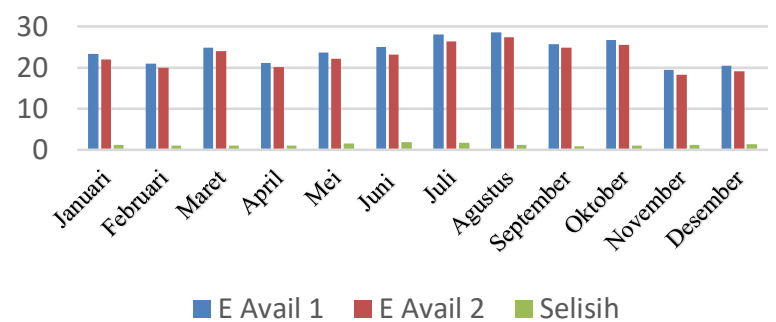

Gambar 10. Grafik Perbandingan Hasil Simulasi

Perbedaan hasil simulasi software PVSyst pada kondisi skenario 1 dan skenario 2 yang disebabkan karena adanya shading factor ini dapat disebabkan oleh beragam hal disekitar lokasi PLTS yang mendukung terjadinya fenomena ini. Salah satunya adalah tata letak bangunan disekitar Panel surya yang lebih tinggi dan menghalangi Panel surya guna mendapatkan penyinaran sinar matahari secara optimal sesuai dengan pemasangan Panel surya yang optimum dilokasi PLTS tersebut. Bangunan yang lebih tinggi tentu saja dapat memberikan bayangan pada Panel surya ketika sinar matahari berada sejajar dengan bangunan dan Panel surya tersebut sehingga kinerja Panel surya tidak optimal. Tak hanya bangunan saja, namun pepohonan yang rimbun dan lingkungan disekitar PLTS pun dapat menjadi salah satu penyebab shading factor yang menghalangi kinerja Panel surya secara optimal.

\subsection{Analisis Produksi Energi Listrik PLTS}

Berdasarkan simulasi perencanaan PLTS Departemen Teknik Elektro Universitas Diponegoro menggunakan skenario 1 dan skenario 2 didapatkan hasil produksi energi listrik yang berbeda tiap bulannya. Tidak hanya shading factor saja yang mempengaruhi produksi energi listrik PLTS Departemen Teknik Elektro Universitas Diponegoro. Namun hal ini dipengaruhi pula oleh beragam faktor lainnya, diantaranya adalah:
1. Waktu Insolasi Matahari

Waktu insolasi matahari cukup mempengaruhi kinerja dan produksi energi listrik dari sistem Pembangkit Listrik Tenaga Surya Departemen Teknik Elektro Universitas Diponegoro. Hal ini dikarenakan pada tiap bulannya, lama penyinaran matahari memiliki intensitas lama penyinaran yang berbeda yang mengakibatkan kinerja panel surya sebagai komponen utama tidak dapat bekerja secara maksimal sepanjang waktu. Hal ini ditunjang dengan pergerakan bumi yang mengitari matahari atau yang sering disebut dengan revolusi bumi mengakibatkan adanya perubahan musim serta gerak semu tahunan matahari. Sedangkan berputarnya bumi pada porosnya atau rotasi bumi mengakibatkan perbedaan waktu antara siang dan malam serta gerak semu harian matahari.

Tabel 7. Waktu Insolasi dan Tingkat Radiasi Harian Matahari (01/01/2017)

\begin{tabular}{ccc}
\hline $\begin{array}{c}\text { Time } \\
(\mathrm{WIB})\end{array}$ & $\begin{array}{c}\text { GlobHor } \\
\left(\mathrm{W} / \mathrm{m}^{2}\right)\end{array}$ & $\begin{array}{c}\text { DiffHor } \\
\left(\mathrm{W} / \mathrm{m}^{2}\right)\end{array}$ \\
\hline 00.00 & 0 & 0 \\
01.00 & 0 & 0 \\
02.00 & 0 & 0 \\
03.00 & 0 & 0 \\
04.00 & 0 & 0 \\
05.00 & 6 & 5,6 \\
06.00 & 204 & 100,3 \\
07.00 & 474 & 87,4 \\
08.00 & 733 & 89,7 \\
09.00 & 940 & 96,8 \\
10.00 & 1078 & 113,5 \\
11.00 & 1135 & 122,3 \\
12.00 & 1110 & 116,5 \\
13.00 & 1003 & 104,0 \\
14.00 & 821 & 87,1 \\
15.00 & 579 & 90,2 \\
16.00 & 307 & 131,8 \\
17.00 & 28 & 26,8 \\
18.00 & 0 & 0 \\
19.00 & 0 & 0 \\
20.00 & 0 & 0 \\
21.00 & 0 & 0 \\
22.00 & 0 & 0 \\
23.00 & 0 & 0 \\
\hline & &
\end{tabular}

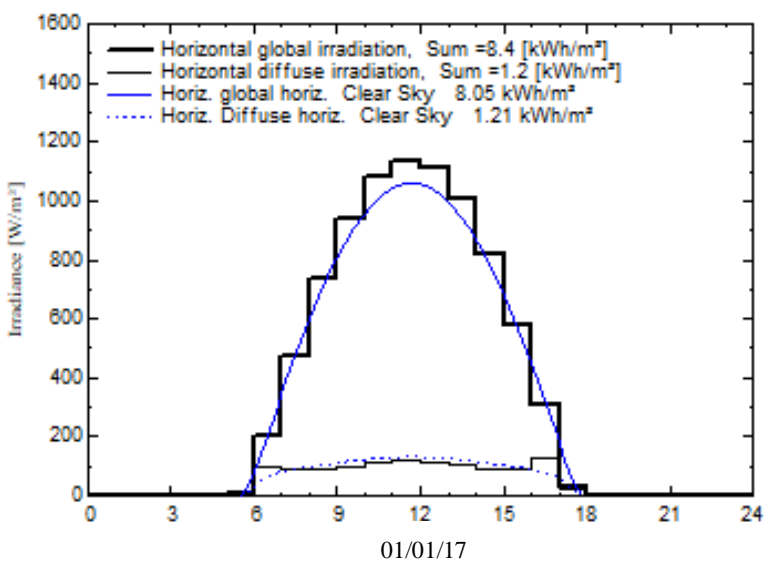

Gambar 11. Grafik Waktu Insolasi Harian Terhadap Tingkat Radiasi Matahari (01/01/2017) 
Berdasarkan tabel 7 dan gambar 11 yang menunjukan hubungan antara waktu insolasi matahari dengan tingkat iradiasi matahari dapat dilihat bahwa kinerja panel surya tidak dapat digunakan secara maksimal karena waktu insolasi matahari yang tidak sama dan terus berubah dari waktu ke waktu yang mengakibatkan produksi energi listrik tiap bulannya berubah dan cenderung fluktuatif.

\section{Tingkat Intensitas Radiasi Matahari}

Tingkat intensitas radiasi matahari atau yang kerap disebut sebagai iradiasi matahari merupakan parameter penting dan utama dalam menentukan potensi perencanaan PLTS beserta sistem dan komponen pendukung yang digunakan. Hal ini dikarenakan prinsip kerja panel surya yang mengkonversi energi panas dari intensitas radiasi matahari menjadi energi listrik searah. Semakin besar tingkat intensitas radiasi matahari maka akan semakin besar pula potensi energi listrik yang dihasilkan oleh PLTS tersebut bergantung dengan efisiensi panel surya dan komponen pendukung lainnya. Sebaliknya, jika tingkat intensitas radiasi matahari kecil maka produksi energi listriknya pun sedikit. Hal ini dapat dibuktikan berdasarkan tabel dan grafik berikut:

Tabel 7. Perbandingan Produksi Energi Listrik dengan Intensitas Radiasi Matahari di Kota Semarang

\begin{tabular}{ccccc}
\hline Bulan & $\begin{array}{c}\text { E Avail 1 } \\
\text { (MWh) }\end{array}$ & $\begin{array}{c}\text { EAvail 2 } \\
(\text { MWh })\end{array}$ & \multicolumn{2}{c}{$\begin{array}{c}\text { Iradiasi Matahari } \\
\left(\mathrm{kWh} / \mathrm{m}^{2}\right)\end{array}$} \\
& & & 2016 & 2017 \\
\hline Januari & 23,258 & 22,04 & 8,624 & 8,62 \\
Februari & 20,959 & 19,94 & 6,318 & 8,216 \\
Maret & 24,859 & 23,92 & 9,173 & 8,577 \\
April & 21,117 & 20,12 & 8,833 & 7,052 \\
Mei & 23,698 & 22,16 & 7,765 & 7,507 \\
Juni & 25,033 & 23,10 & 7,117 & 8,216 \\
Juli & 28,054 & 26,36 & 7,836 & 9,43 \\
Agustus & 28,544 & 27,39 & 8,811 & 10,079 \\
September & 25,706 & 24,87 & 9,322 & 9,37 \\
Oktober & 26,622 & 25,54 & 7,732 & 9,86 \\
November & 19,467 & 18,21 & 8,080 & 7,13 \\
Desember & 20,422 & 19,13 & 7,421 & 7,392 \\
\hline
\end{tabular}

Perbandingan Produksi Energi Listrik dengan Intensitas Radiasi Matahari di Kota Semarang

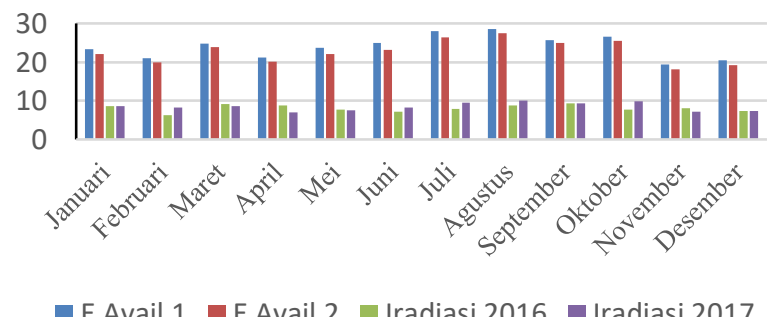

Gambar 11. Grafik Perbandingan Produksi Energi Listrik dengan Intensitas Radiasi Matahari di Kota Semarang
3. Intensitas Curah Hujan dan Perubahan Musim

Tinggi dan rendahnya tingkat produksi energi listrik Pembangkit Listrik Tenaga Surya Departemen Teknik Elektro Universitas Diponegoro juga bergantung pada perubahan cuaca dan iklim di Kota Semarang, Jawa Tengah. Semakin tinggi kadar curah hujan, maka lama penyinaran dan tingkat intensitas radiasi matahari pun akan berkurang yang berdampak pada performa/ kinerja sistem Pembangkit Listrik Tenaga Surya Departemen Teknik Elektro Universitas Diponegoro. Kota Semarang, Jawa Tengah memiliki kadar curah hujan yang berbeda-beda pada setiap bulannya yang mengakibatkan tingkat intensitas radiasi matahari pada musim penghujan berbeda dengan tingkat intensitas radiasi matahari pada musim kemarau ataupun pada musim peralihan/ pancaroba.

Tabel 8. Perbandingan Produksi Energi Listrik dengan Curah Hujan di Kota Semarang

\begin{tabular}{ccccc}
\hline Bulan & $\begin{array}{c}\text { E Avail 1 } \\
\text { (MWh) }\end{array}$ & $\begin{array}{c}\text { E Avail 2 } \\
\text { (MWh) }\end{array}$ & \multicolumn{2}{c}{$\begin{array}{c}\text { Curah Hujan } \\
(\mathrm{mm})\end{array}$} \\
\hline Januari & 23,258 & 22,04 & 277 & 2017 \\
Februari & 20,959 & 19,94 & 214 & 202 \\
Maret & 24,859 & 23,92 & 126 & 89 \\
April & 21,117 & 20,12 & 287 & 266 \\
Mei & 23,698 & 22,16 & 169 & 127 \\
Juni & 25,033 & 23,10 & 57 & 41 \\
Juli & 28,054 & 26,36 & 15 & 8 \\
Agustus & 28,544 & 27,39 & 3 & 0 \\
September & 25,706 & 24,87 & 44 & 33 \\
Oktober & 26,622 & 25,54 & 31 & 25 \\
November & 19,467 & 18,21 & 359 & 345 \\
Desember & 20,422 & 19,13 & 326 & 317 \\
\hline
\end{tabular}

Perbandingan Produksi Energi Listrik Curah Hujan Bulanan di Kota Semarang

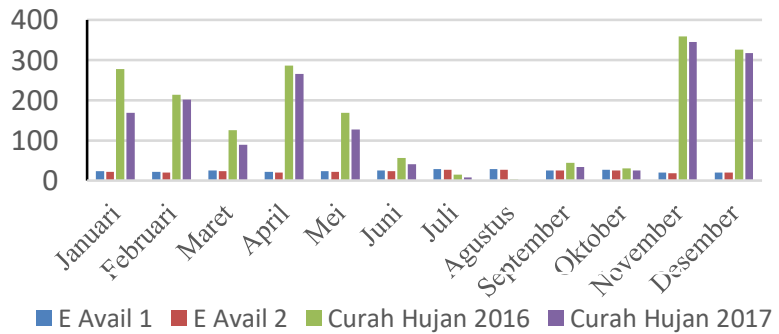

Gambar 12. Grafik Perbandingan Produksi Energi Listrik dengan Curah Hujan di Kota Semarang

Berdasarkan tabel 8 dan gambar 12 dapat diketahui bahwa semakin tinggi tingkat produksi energi listrik oleh Pembangkit Listrik Tenaga Surya Departemen Teknik Elektro Universitas Diponegoro maka kadar curah hujan perbulannya pun semakin kecil (musim kemarau). Begitu pula sebaliknya, semakin besar kadar curah hujan pada bulan tertentu (musim penghujan) maka akan semakin kecil pula produksi energi listrik yang dapat dihasilkan. 


\section{Kesimpulan}

Berdasarkan analisis unjuk kerja perancangan Pembangkit Listrik Tenaga Surya Departemen Teknik Elektro Universitas Diponegoro menggunakan software PVSyst 6.43, dapat disimpulkan bahwa sistem PLTS yang dirancang pada perancangan PLTS Departemen Teknik Elektro Universitas Diponegoro memiliki besar energi listrik yang dihasilkan sebesar 272,8 MWh/tahun, menggunakan 390 buah panel surya dengan sudut kemiringan optimal panel surya adalah $10^{\circ}$. Di mana konsumsi energi listrik Departemen Teknik Elektro Universitas Diponegoro sebesar 355,7 MWh/ tahun dengan 197,67 MWh digunakan guna keperluan sendiri dan 75,110 MWh disalurkan ke jala-jala PLN tiap tahun dengan jumlah produksi terbesar yaitu pada bulan Agustus dan terendah pada bulan April. Adanya faktor bayangan/ shading factor yang terjadi di Pembangkit Listrik Tenaga Surya Departemen Teknik Elektro Universitas Diponegoro sangat mempengaruhi produksi energi listrik di PLTS tersebut. Berdasarkan perbandingan hasil dari simulasi skenario 1 dan skenario 2, adanya shading factor dapat menurunkan produksi energi listrik di PLTS tersebut sebesar $15 \mathrm{MWh}$ atau $5.2 \%$ pertahun.

\section{Referensi}

[1]. Bien, L. E., Perancangan Sistem Hibrid Pembangkit Listrik Tenaga Surya dengan Jala-jala Listrik PLN untuk Rumah Perkotaan, Universitas Trisakti, 2008.

[2]. King, Boyson, \& Kratochvil, Analysis of Factors Influencing the Annual Energy Production of Photovoltaic Systems, IEEE, 2002.Bachtiar,

[3]. CANMET Energy Technology Centre - Varennes (CETC), Photovoltaic Project Analysis Chapter, RETScreen International, 2001 - 2004
[4]. Universitas Diponegoro, 2018. Lokasi Univeritas Diponegoro.https://www.undip.ac.id/language/id/lokasi (diakses pada 15 Juli 2018)

[5]. Muhammad, "Prosedur Perancangan Sistem Pembangkit Listrik Tenaga Surya untuk Perumahan (Solar Home System)", SMARTek, vol.4, no.3, pp. 176-182, 2006.

[6]. Data Intensistas Penyinaran dan Radiasi Matahari 20152017. Badan Meteorologi Klimatologi dan Geofisika (BMKG) Jawa Tengah, Stasiun Klimatologi Semarang, 2014.

[7]. Agus, S, I Kadek, Analisa Unjuk Kerja Pembangkit Listrik Tenaga Surya (PLTS) 1 MWp Terinterkoneksi Jaringan Di Kayubihi, Bangli. Denpasar, Universitas Udayana, 2008

[8]. ABB, Technical Application Papers N0.10 Photovoltaic Plants, Bergamo Italy, 2008.

[9]. Dunlop, James P., Batteries and Charge Control in Stand-Alone Photovoltaic Systems Fundamental and Application, Florida Solar Energy Center/ University of Central Florida, 2008.

[10]. Omran, Walid, Performance Analysis of Grid-Connected Photovoltaic Systems, Electrical and Computer Engineering University of Waterloo, 2010.

[11]. PT LEN Industri (Persero). PLTS On-Grid $200 \mathrm{kWp}$ Gili Trawangan Go Green. Buletin LEN nomor 8 (November 2011): 15-18, 2011.

[12]. International Finance Corporation (IFC), Utility Scale Solar Power Plants. India, 2012.

[13]. Data Listrik Pelanggan 2017. PT. PLN (Persero) Distribusi Jawa Tengah dan DIY, Semarang, 2018.

[14]. Planning and Installing Photovoltaic Systems: A guide for installers, architects and engineers, Earthscan, 2005

[15]. Duffie, John A. and William A. Beckman, Solar Engineering of Thermal Processes,3th, Jon Wiley \& Sons Inc, New Jersey, 2006. 